\title{
STATE OF THE PLATELET HEMOSTASIS IN THE MIDDLE-AGED AND THE ELDERLY HYPERTENSIVE PATIENTS
}

\section{S. Pasko}

State institution of science «Research and practical center of preventive and clinical medicine» State administrative department, Kyiv

\section{СТАН ТРОМБОЦИТАРНОГО ГЕМОСТАЗУ В ХВОРИХ НА ГІПЕРТОНІЧНУ ХВОРОБУ ІІ СТАДІЇ СЕРЕДНЬОГО ТА ПОХИЛОГО ВІКУ}

\author{
Пасько В. С.
}

Державна наукова установа «Науково-практичний центр профілактичної та клінічної медицини» Державного управління справами, Київ, Україна

\section{Резюме}

ЗАавна відомо, що ускладнення гіпертонічної хвороби здебільшого пов'язані з порушеннями у системі згортання крові, а з віком зростає ступінь абсолютного ризику серцево- судинних подій. Ось чому, на теперішній час велика увага приділяеться білыш детальному вивченню механізмів тромбоутворення, як складової ускладнень гіпертонічної хвороби, через призму гемостазіологічних зрушень. Отже, на сьогодні недостатньо вивченими у хворих на гіпертонічну хворобу є регуляторні механізми ініціації тромбоутворення і участі тромбоцитарного гемостазу.

Мета - виявлення вихідного рівня показників тромбоцитарного гемостазу у хворих середнього і похилого віку на гіпертонічну хворобу II стадії.

Матеріал і методи. Аля з'ясування цього питання у нашій роботі ми проводили порівняльну оцінку стану тромбоцитарного гемостазу у 63 хворих середнього (група I) та 53 похилого віку (група II) відповідно. Контрольну групу склали по 15 хворих для кожної з обстежених категорій (відповідно III група - обстежені середнього віку та IV група - обстежені похилого віку) 3 порівнянним статевим складом.

Висновки. Отже, у хворих на гіпертонічну хворобу II стадії середнього і похилого віку відбувається збільшення тромбоцитарної активності залежно від віку, що найбілыш виразно проявляеться при стимуляції адреналіном. У хворих старшої вікової групи, крім того, найбілыш суттеві зміни визначаються при спонтанній та адреналін-індукованій агрегації, а саме ступеня та швидкості агрегації при спонтанній і часу максимальної агрегації при адреналініндукованій агрегації у порівнянні з хворими середнього віку. Істотне уповільнення часу максимальної агрегації тромбоцитів, стимульованої алреналіном, в 1,6 рази $(\mathrm{p}<0,001)$ у хворих похилого віку також підтверджує їх виражену тромбогенність і чутливість до нейрогуморальних впливів. Таким чином, виявлена нами тромбогенність плазми крові при дослідженні тромбоцитарного гемостазу в осіб похилого віку вказує на високу ймовірність розвитку тромботичних ускладнень у цієї категорії хворих, і це узгоджується з даними літератури.

Ключові слова: артеріальна гіпертензія, гіпертонічна хвороба, тромбоцитарний гемостаз.

It has long been known that complications of essential hypertension $(\mathrm{EH})$ are associated mostly with disorders of blood coagulation system [4, 14] and degree of absolute risk of cardiovascular events is growing with increas- ing of age $[10,12,13]$. That is why much attention is paid to more detailed study of mechanisms of thrombosis as the component of complications of EH through lens of hemostatic changes at present [6]. Therefore, regulatory 
mechanisms of initiation of thrombus formation and participation of platelet hemostasis are studied in hypertensive patients insufficiently today.

Situation has changed in recent years: epidemiological and experimental data have emerged to ascertain presence of prothrombotic changes in system of hemostasis in EH. Typical disorders in hemostasis system in EH are considered as a significant risk factor for thrombophilic complications $[1,2,5,15]$. Thromboembolic conditions are observed in $56 \%$ of patients and are a direct cause of death in $49 \%$ of cases, hemorrhage - in 35\% [11].

Data on importance in predicting of development of cerebral stroke and myocardial infarction of such factor of hemocoagulation as platelet dysfunction have been obtained in recent years $[2,9]$. The key element in processes of atherothrombosis is platelet activation [11]. The blood platelets are the matrix for the coagulation cascade $[3,5]$. Changes in a functional state of platelets, bioenergetic and plastic processes occurring in these cells are related directly to hemostasis as a whole and may indicate severity of cardiovascular damage [8]. However a functional activity of platelets is understood poorly still.

One of the components of Virkhov triad is an impaired blood composition namely the factors of platelet coagulation and activation. Imbalance of platelet-plasma hemostasis leads to development of complications in arterial hypertension (AH) [16].

Changes in functional properties of platelets in patients with EH are accompanied by release of vasoactive mediators that provoke local vasospasm and increase platelet aggregation which magnifies risk of thrombotic complications. The leading link of enhanced thrombus formation is increased platelet aggregation in $\mathrm{AH}$ [9]. The platelets of the patients with $\mathrm{EH}$ have the increased sensitivity to ADP. Dockrell M. et al. showed the positive correlation of blood pressure with potentiation by endothelin-1 of the adrenaline-induced platelet aggregation which can be considered as the manifestation of familial susceptibility to EH in their studies [13].

There are few work concerns study of platelet hemostasis in patients with AH especially in older age groups.

This article is an attempt to systematize and analyze few literary data on role of hemostasis system in pathogenesis of EH in the elderly.

The objective of the study. To identify the baseline levels of the platelet hemostasis indices in the middle-aged and the elderly hypertensive patients.

\section{MATHERIAL AND METHODS}

We performed the comparative assessment of status of the platelet hemostasis in 63 middle-aged (group I) and 53 elderly patients (group II) respectively to clarify this issue in our work. Patients of the surveyed groups were comparable in age, sex and related pathology. The control group consisted of 15 patients for every of the surveyed groups (group III the middle-aged and group IV the elderly respectively) matched with basic by age and gender. The control was presented with patients without AH who were hospitalized with diagnoses of chronic gastritis, duodenitis, cholecystitis, aterosclerotic cardiosclerosis, with angina functional class that is not above I, without cardiac arrhythmias and heart failure that is not above II A stage for Strazhesko M. D.- Vasylenko V. Kh.

The diagnosis and stage of EH was set according to the criteria of WHO and the International Society of Hypertension (2013). Patients with significant heart rhythm disorders, angina functional class that is above I, heart failure that is above II A stage for Strazhesko M. D.- Vasylenko V. Kh. were not involved in the study. Cases with symptomatic hypertension and obesity more than the second degree were also excluded.

Spontaneous and induced platelet aggregations were determined. Platelets were activated with adenosine diphosphate (ADP) $\left(1 \times 10^{-5} \mathrm{mM} / \mathrm{L}\right)$, adrenaline $(1 \mu \mathrm{g} / \mathrm{mL})$ and analysed by optical aggregometry (SOLAR AP-2110). We determined and analyzed the following indices: amplitude of aggregation (AA) (\%), time of maximal aggregation (TMA) (min.), slope of aggregation (SA) (\%/min.).

\section{RESULTS AND DISCUTION}

The parameters of the platelet hemostasis in the middle-aged hypertensive patients were compared with the corresponding indicators of the elderly hypertensive patients according to the stated purpose and tasks. Analyzing the obtained data of the platelet hemostasis indices in particular the spontaneous aggregation it is noteworthy that AA and SA were different significantly among the compared indicators.

So, AA was higher by $23,1 \%(\mathrm{p}<0,05)$ in the elderly and was $3,2 \pm 1,7 \%$ respectively and $2,6 \pm 1,7 \%$ in the middle-aged; $\mathrm{SA}-$ by $46,7 \%(2,2 \pm 1,7 \% / \mathrm{min}$. and $1,5 \pm 1,2 \% / \mathrm{min}$. respectively). The acceleration of the aggregation process was detected by $46,7 \%(p<0,05)$ in the elderly compared with the patients of the middle age (tab. 1).

TMA index in the middle-aged patients was $27,3 \%$ $(\mathrm{p}<0,05)$ higher than in the control group.

We found the significant slowdown of the aggregation process in the elderly patients by $33,3 \%(\mathrm{p}<0,05)$ compared to the control values analyzing the velocity of it.

Thus, the comparison of the obtained indices of the spontaneous platelet aggregation in hypertensive patients of the different age categories established the informative content of AA in the elderly patients, which exceeded significantly the similar indicator in patients of the middle age by $23,1 \%(\mathrm{p}<0,05)$. Thereby, the aggregation process acceleration was detected by $46,7 \%(\mathrm{p}<0,05)$ in the elderly patients compared with the middle-aged patients. 
The indices of the spontaneous platelet aggregation in the middle-aged and the elderly patients $(\mathrm{M} \pm \sigma)$

\begin{tabular}{|c|c|c|c|c|c|}
\hline \multirow[b]{2}{*}{ The indices } & \multicolumn{4}{|c|}{ The distribution of the surveyed groups } & \multirow[b]{2}{*}{$\mathrm{p}$} \\
\hline & $\begin{array}{c}\text { I group } \\
(\mathrm{n}=63)\end{array}$ & $\begin{array}{c}\text { II group } \\
(\mathrm{n}=53)\end{array}$ & $\begin{array}{c}\text { III group } \\
(\mathrm{n}=15)\end{array}$ & $\begin{array}{c}\text { IV group } \\
(n=15)\end{array}$ & \\
\hline $\mathrm{AA}(\%)$ & $2,6 \pm 1,7$ & $3,2 \pm 1,7$ & $1,8 \pm 0,3$ & $2,5 \pm 0,2$ & $\begin{array}{l}\mathrm{p}_{1}<0,05 \\
\mathrm{p}_{2}>0,05 \\
\mathrm{p}_{3}>0,05\end{array}$ \\
\hline TMA (min.) & $5,6 \pm 3,2$ & $6,8 \pm 2,9$ & $4,4 \pm 1,7$ & $8,8 \pm 0,8$ & $\begin{array}{l}\mathrm{p}_{1}>0,05 \\
\mathrm{p}_{2}<0,05 \\
\mathrm{p}_{3}>0,05\end{array}$ \\
\hline $\mathrm{SA}(\% / \mathrm{min})$. & $1,5 \pm 1,2$ & $2,2 \pm 1,7$ & $1,1 \pm 0,2$ & $3,3 \pm 1,3$ & $\begin{array}{l}\mathrm{p}_{1}<0,05 \\
\mathrm{p}_{2}>0,05 \\
\mathrm{p}_{3}<0,05\end{array}$ \\
\hline
\end{tabular}

Remark: p1 - statistical significance of difference between groups I and II, p2 - statistical significance of difference between groups I and III, p3 - statistical significance of difference between groups II and IV.

Analysis of the induced platelet aggregation with the different inductors in the middle-aged and the elderly hypertensive patients showed the greatest informative of TMA under the conditions of the adrenaline stimulation.

Thus, TMA was $6,4 \pm 2,9$ min. in the elderly patients vs. $4,1 \pm 2,0 \mathrm{~min}$. in the patients of the middle age. It was found the significant slowdown in terms of TMA by $56,1 \%$ in the elderly relative to the middle-aged patients $(\mathrm{p}<0,001)$ (tab. 2).

We found the significant increase in ADP-induced platelet aggregation activity in AA by $61,4 \%(p<0,01)$ in the elderly hypertensive patients relative to the control group.

The induced platelet aggregation indices in the middle-aged and the elderly patients $(\mathrm{M} \pm \sigma)$

The table 2

\begin{tabular}{|c|c|c|c|c|c|c|}
\hline \multirow{2}{*}{ The indices } & \multirow[b]{2}{*}{ The inductors } & \multicolumn{4}{|c|}{ The groups } & \multirow[b]{2}{*}{$\mathrm{p}$} \\
\hline & & $\begin{array}{c}\text { I group } \\
(\mathrm{n}=63)\end{array}$ & $\begin{array}{c}\text { II group } \\
(\mathrm{n}=53)\end{array}$ & $\begin{array}{c}\text { III group } \\
(\mathbf{n}=15)\end{array}$ & $\begin{array}{c}\text { IV group } \\
(n=15)\end{array}$ & \\
\hline \multirow{2}{*}{$\mathrm{AA}(\%)$} & ADP & $57,2 \pm 31,1$ & $56,5 \pm 28,7$ & $27,8 \pm 1,9$ & $35,0 \pm 4,9$ & $\begin{array}{l}\mathrm{p}_{1}>0,05 \\
\mathrm{p}_{2}>0,05 \\
\mathrm{p}_{3}<0,01\end{array}$ \\
\hline & Adrenaline & $29,0 \pm 17,3$ & $35,6 \pm 32,1$ & $35,2 \pm 2,6$ & $42,9 \pm 5,6$ & $\begin{array}{l}\mathrm{p}_{1}>0,05 \\
\mathrm{p}_{2}>0,05 \\
\mathrm{p}_{3}>0,05\end{array}$ \\
\hline \multirow{2}{*}{ TMA (min.) } & ADP & $4,3 \pm 2,1$ & $5,0 \pm 2,4$ & $4,7 \pm 1,0$ & $6,9 \pm 1,4$ & $\begin{array}{l}\mathrm{p}_{1}>0,05 \\
\mathrm{p}_{2}>0,05 \\
\mathrm{p}_{3}>0,05\end{array}$ \\
\hline & Adrenaline & $4,1 \pm 2,0$ & $6,4 \pm 2,9$ & $4,9 \pm 0,2$ & $8,2 \pm 1,8$ & $\begin{array}{c}\mathrm{p}_{1}<0,001 \\
\mathrm{p}_{2}>0,05 \\
\mathrm{p}_{3}>0,05\end{array}$ \\
\hline \multirow{2}{*}{$\mathrm{SA}(\% / \mathrm{min})}$. & ADP & $52,3 \pm 26,9$ & $53,7 \pm 21,8$ & $27,4 \pm 10,7$ & $49,9 \pm 11,8$ & $\begin{array}{l}\mathrm{p}_{1}>0,05 \\
\mathrm{p}_{2}>0,05 \\
\mathrm{p}_{3}>0,05\end{array}$ \\
\hline & Adrenaline & $12,0 \pm 5,9$ & $15,4 \pm 12,6$ & $15,4 \pm 1,3$ & $18,0 \pm 1,5$ & $\begin{array}{l}\mathrm{p}_{1}>0,05 \\
\mathrm{p}_{2}>0,05 \\
\mathrm{p}_{2}>0,05\end{array}$ \\
\hline
\end{tabular}

Remark: $p_{1}$ - statistical significance of difference between groups I and II, $p_{2}-$ statistical significance of difference between groups I and III, $\mathrm{p}_{3}$ - statistical significance of difference between groups II and IV.

\section{CONCLUSIONS}

Therefore, there is the increase in platelet activity depending on age in the middle-aged and the elderly hypertensive patients that is manifested by adrenaline stimulation most clearly. In addition, the most significant changes are determined in the spontaneous and the adrenaline-induced aggregation namely in amplitude and slope of aggregation in the spontaneous and time of maximal aggregation in the adrenaline-induced aggregation in the patients of older age group compared with the middle-aged patients. The substantial deceleration of time of maximal aggregation 
during the adrenaline stimulated aggregation in 1,6 times $(\mathrm{p}<0,001)$ in the elderly patients confirms the expressed thrombogenicity and sensitiveness to neurohumoral influences too. Thus, the blood plasma thrombogenicity re- vealed in the study of the platelet hemostasis in the elderly indicates a high probability of thrombotic complications developing in this category of the patients and this is consistent with literature [7].

\section{ЛІТЕРАТУРА}

1. Баркаган 3. С., Момот А. П. Диагногстика и контролируемая терапия нарушений гемостаза. Москва: Ньюдиамед. 2001. 296 с.

2. Братчик А. М. Клинические проблемы фибринолиза. К.: Здоровья, 1993. 343 с.

3. Волков Г. Л., Платонова Т. Н., Савчук А. Н., Горницкая О. В., Чернышенко Т. М., Краснобрижая Е. Н. Современные представления о системе гемостаза. Киев: Наукова думка, 2005. 296 с.

4. Грицюк А. И., Амосова Е. Н., Грицюк И. А. Практическая гемостазиология. К.: Здоров’я, 1994. 256 с.

5. Дранник Г.Н., Ена Я. М., Варецкая Т. В. Продукты расщепления фибрина/фибриногена при патологических процессах. К.: Здоровье, 1987. 184 с.

6. Иванов Е. П. Диагностика нарушений гемостаза. Минск: Беларусь, 1983. 223 с.

7. Коркушко О. В., Коваленко А. Н. Система свертывания крови при старении. К.: Здоровье, 1988. $216 \mathrm{c}$.

8. Крамарева В. Н., Луговской Э. В. Показатели свертывающей системы крови и противотромботические механизмы у больных эссенциальной артериальной гипертензией. Український медичний часопис. 2010. № 3 (77). С. 104-106.

9. Медведев И. Н., Громнацкий Н. И. Коррекция тромбоцитарного гемостаза и снижение биологи- ческого возраста при метаболическом синдроме. Клиническая медицина. 2005. № 8. С. 54-57.

10. Моисеев В. С., Кобалова Ж. Д. АРГУС Артериальная гипертония у лиц старших возрастных групп. М.: ООО «Медицинское информационное агентство», 2002. 448 с.

11. Панченко Е. П., Добровольский А. Б. Тромбозы в кардиологии. Механизмы развития и возможности терапии. Москва: Спорт и культура, 1999. С. 12-22.

12. Приходько В. Ю. Артеріальна гіпертензія і вік: поширеність, особливості перебігу та ускладнення. Мистецтво лікування. 2006. № 7 (33). С. 23-31.

13. Репин А. Н., Сергиенко Т. Н., Карпов Р. С. Лечение артериальной гипертензии у пожилых больных. Системные гипертензии. 2007. № 2. С. 54-61.

14.Kesmarsky G., Marton Z., Toth K. Haemorheological variables as risk factors of ischaemic heart diesases. Eur. Heart J. 2005. Vol. 26. P. 624-625.

15. Remková A., Remko M. The role of renin-angiotensin system in prothrombotic state in essential hypertension. Physiol. Res. 2010. № 59 (1). P. 13-23.

16. Tabak O., Gelisgen R., Uzun H., Kalender B., Balci H., Curgunlu A., Simsek G., Karter Y. Hypertension and hemostatic/fibrinolytic balance disorders. Clin. Invest. Med. 2009. № 32 (6). P. 285-292.

\section{REFERENCES}

1. Barkagan Z. S., Momot A. P. (2001). Diagnogstika i kontroliruyemaya terapiya narusheniy gemostaza [Diagnostics and controlled therapy of hemostasis disorders]. Moskva: N'yudiamed, 296.

2. Bratchik A. M. (1993). Klinicheskiye problemy fibrinoliza [Clinical problems of fibrinolysis]. K.: Zdorov’ya, 343.

3. Volkov G. L., Platonova T. N., Savchuk A. N., Gornitskaya O. V., Chernyshenko T. M., Krasnobrizhaya Ye. N. (2005). Sovremennyye predstavleniya o sisteme gemostaza [Modern ideas about hemostasis system]. Kiev: Naukova dumka, 296.

4. Gritsyuk A. I., Amosova Ye. N., Gritsyuk I. A. (1994). Prakticheskaya gemostaziologiya [Practical hemostasiology]. K.: Zdorov’ya, 256.
5. Drannik G. N., Yena Ya. M., Varetskaya T. V. (1987). Produkty rasshchepleniya fibrina/fibrinogena pri patologicheskikh protsessakh [Fibrin/fibrinogen cleavage products in pathological processes]. K.: Zdorov'ye, 184.

6. Ivanov Ye. P. (1983). Diagnostika narusheniy gemostaza [Diagnostics of hemostatic disorders]. Minsk: Belarus', 223.

7. Korkushko O. V., Kovalenko A. N. (1988). Sistema svertyvaniya krovi pri starenii [Blood coagulation system during aging]. K.: Zdorov'ye, 216.

8. Kramareva V. N., Lugovskoy E. V. (2010). Pokazateli svertyvayushchey sistemy krovi i protivotromboticheskiye mekhanizmy u bol'nykh essentsial'noy arterial'noy gipertenziyey [Blood coagulation parameters and antithrombotic mechanisms in patients with essential ar- 
terial hypertension]. Ukrainian medical magazine, 3 (77), 104-106.

9. Medvedev I. N., Gromnatskiy N. I. (2005). Korrektsiya trombotsitarnogo gemostaza i snizheniye biologicheskogo vozrasta pri metabolicheskom sindrome [Correction of platelet hemostasis and decrease in biological age in metabolic syndrome]. Clinical medicine, 8, 54-57.

10. Moiseyev V. S., Kobalova Zh. D. (2002). ARGUS Artepial'naya gipertoniya u lits starshikh vozrastnykh grupp [Arterial hypertension in people of older age groups]. M.: OOO «Meditsinskoye informatsionnoye agentstvo», 448.

11. Panchenko Ye. P., Dobrovol'skiy A. B. (1999). Trombozy v kardiologii. Mekhanizmy razvitiya i vozmozhnosti terapii [Thrombosis in cardiology. Development mechanisms and treatment options]. Moskva: Sport i kul'tura, 12-22.

12.Prikhod'ko V. Yu. (2006). Arteríal'na gípertenzíya í vík: poshireníst', osoblivostí perebígu ta uskladnennya [Ar- terial hypertension and age: prevalence, features and complications]. Art of healing, 7 (33), 23-31.

13. Repin A. N., Sergienko T. N., Karpov, R. S. (2007). Lechenie arterialnoy gipertenzii u pojilyih bolnyih [Treatment of arterial hypertension in elderly patients]. Systemic hypertension, 2, 54-61.

14.Kesmarsky G., Marton Z., Toth K. (2005). Haemorheological variables as risk factors of ischaemic heart diesases. Eur. Heart J., 26, 624-625.

15. Remková A., Remko M. (2010). The role of reninangiotensin system in prothrombotic state in essential hypertension. Physiol. Res., 59 (1), 13-23.

16. Tabak O., Gelisgen R., Uzun H., Kalender B., Balci H., Curgunlu A., Simsek G., Karter Y. (2009). Hypertension and hemostatic/fibrinolytic balance disorders. Clin. Invest. Med., 32 (6), 285-292.

\section{Резюме}

\section{СОСТОЯНИЕ ТРОМБОЦИТАРНОГО ГЕМОСТАЗА У БОЛЬНЫХ ГИПЕРТОНИЧЕСКОЙ БОЛЕЗНЬЮ ІІ СТАДИИ СРЕДНЕГО И ПОЖИЛОГО ВОЗРАСТА}

Пасько В. С.

\section{Государственное научное учреждение « Научно-практический центр профилактической и клинической медицины»} Государственного управления делами, Киев, Украина

Издавна известно, что осложнения гипертонической болезни в основном связаны с нарушениями в системе свертывания крови, а с возрастом возрастает степень абсолютного риска сердечно-сосудистых событий. Вот почему, в настоящее время большое внимание уделяется более детальному изучению механизмов тромбообразования, как составляющей осложнений гипертонической болезни, через призму гемостазиологических сдвигов. Итак, на сегодня недостаточно изученными у больных гипертонической болезнью являются регуляторные механизмы инициации тромбообразования и участия тромбоцитарного гемостаза.

Цель - выявление исходного уровня показателей тромбоцитарного гемостаза у больных среднего и пожилого возраста с гипертонической болезнью II стадии.

Материал и методы. Аля выяснения этого вопроса в нашей работе мы проводили сравнительную оценку состояния тромбоцитарного гемостаза у 63 больных среднего (группа I) и 53 пожилого возраста (группа II) соответственно. Контрольную группу составили по 15 больных для каждой из обследованных категорий (соответственно III группа - обследованные среднего возраста и IV группа - обследованные пожилого возраста) с сопоставимым половым составом.

Выводы. Следовательно, у больных гипертонической болезнью II стадии среднего и пожилого возраста происходит увеличение тромбоцитарной активности в зависимости от возраста, что наиболее отчетливо проявляется при стимуляции ахреналином. У больных старшей возрастной группы, кроме того, наиболее существенные изменения определяются при спонтанной и адреналин-индуцированной агрегации, а именно степени и скорости агрегации при спонтанной и времени максимальной агрегации при адреналин-индуцированной агрегации по сравнению с больными среднего возраста. Существенное замедление времени максимальной агрегации тромбоцитов, стимулированной адреналином, в 1,6 раза $(\mathrm{p}<0,001)$ у больных пожилого возраста также подтверждает их выраженную тромбогенность и чувствительность к нейрогуморальным воздействиям. Таким образом, обнаруженная нами тромбогенность плазмы крови при исследовании тромбоцитарного гемостаза у лиц пожилого возраста указывает на высокую вероятность развития тромботических осложнений у этой категории больных, и это согласуется с данными литературы.

Ключевые слова: артериальная гипертензия, гипертоническая болезнь, тромбоцитарный гемостаз. 


\section{Summary}

\section{STATE OF THE PLATELET HAEMOSTSIS IN THE THE MIDDLE-AGED AND THE ELDERLY HYPERTENSIVE PATIENTS V. S. Pasko}

State institution of science «Research and practical center of preventive and clinical medicine» State administrative department, Kyiv

It has long been known that complications of essential hypertension are associated mostly with disorders of blood coagulation system and degree of absolute risk of cardiovascular events is growing with increasing of age. That is why much attention is paid to more detailed study of mechanisms of thrombosis as the component of complications of essential hypertension through lens of hemostatic changes at present. Therefore, regulatory mechanisms of initiation of thrombus formation and participation of platelet hemostasis are studied in hypertensive patients insufficiently today.

The aim of the study was to identify the baseline levels of the platelet hemostasis indices in the middle-aged and the elderly hypertensive patients.

Material and methods. We performed the comparative assessment of status of the platelet hemostasis in 63 middle-aged (group I) and 53 elderly patients (group II) respectively to clarify this issue in our work. Patients of the surveyed groups were comparable in age, sex and related pathology. The control group consisted of 15 patients for every of the surveyed groups (group III the middle-aged and group IV the elderly respectively) matched with basic by age and gender.

Conclusions. Therefore, there is the increase in platelet activity depending on age in the middle-aged and the elderly hypertensive patients that is manifested by adrenaline stimulation most clearly. In addition, the most significant changes are determined in the spontaneous and the adrenaline-induced aggregation namely in amplitude and slope of aggregation in the spontaneous and time of maximal aggregation in the adrenalineinduced aggregation in the patients of older age group compared with the middle-aged patients. The substantial deceleration of time of maximal aggregation during the adrenaline stimulated aggregation in 1,6 times $(p<0,001)$ in the elderly patients confirms the expressed thrombogenicity and sensitiveness to neurohumoral influences too. Thus, the blood plasma thrombogenicity revealed in the study of the platelet hemostasis in the elderly indicates a high probability of thrombotic complications developing in this category of the patients and this is consistent with literature.

Keywords: arterial hypertension, essential hypertension, platelet hemostasis.

Інформація про авторів знаходиться на сайті http://www.cp-medical.com.

Дата надходження до редакції-20.11.2019 